(c) American Dairy Science Association, 2004.

\title{
Influence of Prepartum Pirlimycin Hydrochloride or Penicillin-Novobiocin Therapy on Mastitis in Heifers During Early Lactation
}

\author{
S. P. Oliver, ${ }^{1}$ B. E. Gillespie, ${ }^{1}$ S. J. Ivey, ${ }^{1}$ M. J. Lewis, ${ }^{1}$ \\ D. L. Johnson, ${ }^{1}$ K. C. Lamar, ${ }^{1}$ H. Moorehead, ${ }^{1}$ H. H. Dowlen, ${ }^{1}$ \\ S. T. Chester, ${ }^{2}$ and J. W. Hallberg ${ }^{2}$ \\ ${ }^{1}$ Department of Animal Science and the Food Safety Center \\ of Excellence, Institute of Agriculture, \\ The University of Tennessee, Knoxville 37996 \\ ${ }^{2}$ Pfizer Animal Health, Kalamazoo, MI 49001
}

\begin{abstract}
A study was conducted in 2 dairy research herds to determine whether prepartum therapy of heifer mammary glands with penicillin-novobiocin or pirlimycin hydrochloride was effective for reducing the percentage of heifers and mammary quarters infected with mastitis pathogens during early lactation. Almost $96 \%$ of Jersey heifers ( 67 of 70 ) and $71.3 \%$ of quarters (199 of 279) were infected $14 \mathrm{~d}$ before expected calving. Of the quarters infected at $14 \mathrm{~d}$ before expected parturition, $75 \%$ (54 of 72 ) were uninfected following treatment with penicillinnovobiocin; $87 \%$ (61 of 70 ) were uninfected following treatment with pirlimycin, and 56\% (32 of 57) were uninfected in the untreated negative control group. The majority of intramammary infections in Jersey heifers were due to coagulase-negative staphylococci $(61 \%)$, Streptococcus species, primarily Streptococcus uberis (19\%), and Staphylococcus aureus (8\%). Almost 73\% of Holstein heifers (40 of 55) and 34.3\% of mammary quarters (73 of 213) were infected $14 \mathrm{~d}$ before expected calving. Of the quarters infected at $14 \mathrm{~d}$ before expected parturition, $76 \%$ (19 of 25) were uninfected following treatment with penicillin-novobiocin; 59\% (17 of 29) were uninfected following treatment with pirlimycin, and $26 \%$ (5 of 19) were uninfected in the untreated negative control group. The majority of intramammary infections in Holstein heifers were due to coagulasenegative staphylococci (44\%) and Staph. aureus (30\%). In both herds, the bacteriological cure rate was significantly higher in heifer mammary glands treated with penicillin-novobiocin or pirlimycin hydrochloride than in untreated controls. Prepartum therapy of heifer mammary glands with penicillin-novobiocin or pirlimycin hydrochloride significantly reduced the percent-
\end{abstract}

Received September 2, 2003.

Accepted January 20, 2004.

Corresponding author: S. P. Oliver; e-mail: soliver@utk.edu. age of heifers and quarters infected with mastitis pathogens during early lactation.

(Key words: heifer, mastitis, intramammary infection, prepartum and peripartutrient period)

\section{INTRODUCTION}

Intramammary infections in breeding age and pregnant heifers are much higher than previously thought. Oliver and Mitchell (1983) showed that a high percentage of pregnant heifer mammary glands were infected during late gestation, at calving, and during early lactation. Several additional studies on the prevalence of mastitis in heifers have been published (Oliver, 1987; Oliver and Sordillo, 1988; Trinidad et al., 1990a; Pankey et al., 1991; Matthews et al., 1992; Smith et al., 1994; Fox et al., 1995; Nickerson et al., 1995), and all of these studies suggest that IMI in heifers during the peripartum period occur frequently.

Many IMI in heifers can persist for long periods of time (Oliver et al., 2003b), are associated with elevated SCC (Trinidad et al., 1990b; Hallberg et al., 1995), impair mammary development during gestation (Trinidad et al., 1990b) and affect milk production after calving (Oliver et al., 2003b). Studies by Oliver et al. (1992, 1997, 2003b) demonstrated that prepartum intramammary infusion of heifer mammary glands with cephapirin sodium or sodium cloxacillin approximately 1 to 2 wk before expected calving was an effective procedure for eliminating many infections in heifers during late gestation and for reducing the prevalence of mastitis in heifers both during early lactation and throughout lactation. Oliver et al. (2003b) also reported that prepartum antibiotic-treated heifers milked significantly longer, produced significantly more milk, and had significantly lower SCC scores than untreated control heifers. These observations are likely associated with or due to the lower prevalence of mastitis pathogen isolation in prepartum antibiotic-treated heifers throughout lacta- 
tion. The objective of the present study was to determine the efficacy of pirlimycin hydrochloride and penicillin-novobiocin intramammary antibiotic therapy of heifer mammary glands at $14 \mathrm{~d}$ before expected calving on mastitis during early lactation.

\section{MATERIALS AND METHODS}

This study was conducted with pregnant Holstein heifers $(n=55)$ at The University of Tennessee Middle Tennessee Experiment Station (MTES) dairy herd, Spring Hill, and pregnant Jersey heifers $(n=70)$ at The University of Tennessee Dairy Experiment Station (DES) dairy herd, Lewisburg. Heifers were blocked by expected date of calving and heifers on each dairy were assigned randomly to blocks with each block containing 3 heifers. Treatment groups were as follows: 1) intramammary infusion of all mammary quarters with a lactating cow antibiotic preparation containing $150 \mathrm{mg}$ of novobiocin sodium plus 100,000 IU of penicillin G procaine (Albacillin, Pfizer Animal Health, Kalamazoo, MI ) $14 \mathrm{~d}$ before expected calving, 2) intramammary infusion of all mammary quarters with a lactating cow antibiotic preparation containing $50 \mathrm{mg}$ of pirlimycin hydrochloride (Pirsue, Pfizer Animal Health, Kalamazoo, MI) $14 \mathrm{~d}$ before expected calving, and 3) no intramammary infusion (negative control) but sampled following the protocol identified for heifers in treatments 1 and 2.

Duplicate samples of mammary secretion were collected aseptically $14 \mathrm{~d}$ prior to expected calving. Single foremilk samples were collected aseptically at 7, 14, and $30 \mathrm{~d}$ after calving. Samples from one mammary quarter of a Jersey heifer and 7 mammary quarters of Holstein heifers were not collected because these mammary glands were nonfunctional and therefore contained little to no secretion. All samples obtained during lactation were collected immediately before regular milking using standard procedures described by the National Mastitis Council (Hogan et al., 1999). Before sample collection, teats were dipped in a premilking teat disinfectant, cleaned thoroughly, and dried with individual disposable paper towels, and teat ends were sanitized with swabs containing $70 \%$ isopropyl alcohol.

Milk samples were examined following procedures recommended by the National Mastitis Council (Hogan et al., 1999). Samples of mammary secretion $(10 \mu \mathrm{L})$ from each mammary gland were plated onto one quadrant of a trypticase soy agar plate supplemented with 5\% defibrinated sheep blood (Becton Dickinson and Company, Franklin Lakes, NJ). Plates were incubated at $37^{\circ} \mathrm{C}$, and bacterial growth was observed and recorded at 24 -h intervals for $3 \mathrm{~d}$. Bacteria on primary culture medium were identified tentatively according to colony morphologic features, hemolytic characteristics, Gram stain reaction, and catalase test. Isolates identified presumptively as staphylococci were tested for coagulase production by the tube coagulase method. Isolates identified presumptively as streptococci were evaluated initially for growth in $6.5 \% \mathrm{NaCl}$, hydrolysis of esculin and sodium hippurate, and CAMP reaction. Streptococcal organisms were identified to the species level using the API 20 Strep system (bioMérieux Inc., Hazelwood, MO) and a streptococcal agglutination system (Streptex, Remel, Lenexa, KS). Gram-negative isolates were identified to the species level using the following biochemical tests: triple sugar iron, urea, oxidase, motility, indole, and ornithine decarboxylase and by the API $20 \mathrm{E}$ identification system (bioMérieux Inc.).

A quarter was considered infected during the prepartum period if at least $1 \mathrm{cfu} / 10 \mu \mathrm{L}$ of sample of the same pathogen was isolated from duplicate samples obtained $14 \mathrm{~d}$ before expected calving. Generally, there were several colony-forming units ( 10 to $>100 / 10 \mu \mathrm{L}$ of sample) of the same mastitis pathogen in duplicate samples. If one of the duplicate samples contained a mastitis pathogen and the other duplicate sample did not, that mammary quarter was considered uninfected regardless of the number of colony-forming units observed in the one sample. A quarter was considered infected during early lactation if at least $1 \mathrm{cfu} / 10 \mu \mathrm{L}$ of sample of the same organism isolated during the prepartum period was obtained at 7,14 , or $30 \mathrm{~d}$ after calving. A quarter was considered chronically infected if at least $1 \mathrm{cfu} / 10 \mu \mathrm{L}$ of sample of the same mastitis pathogen(s) isolated during the prepartum period was isolated 7, 14 , and $30 \mathrm{~d}$ after calving. A bacteriological cure was defined as an infection observed during the prepartum period that was negative for the presence of previously identified bacteria at 7, 14, and $30 \mathrm{~d}$ after calving. A quarter was considered newly infected during early lactation if at least $1 \mathrm{cfu} / 10 \mu \mathrm{L}$ of sample of the same organism was isolated in 2 of 3 samples obtained at 7 , 14, and $30 \mathrm{~d}$ after calving. Treatment comparisons within herd were done using Pearson's chi-square test (SAS release 8.02, SAS Institute Inc., Cary, NC).

\section{RESULTS AND DISCUSSION}

Almost $96 \%$ of Jersey heifers (67 of 70 ) and $71.3 \%$ of mammary quarters (199 of 279) were infected $14 \mathrm{~d}$ before expected calving. Of the quarters infected at $14 \mathrm{~d}$ before expected parturition, 75\% (54 of 72) were uninfected following treatment with penicillin-novobiocin; $87 \%$ (61 of 70) were uninfected following treatment with pirlimycin, and $56 \%$ (32 of 57) were uninfected in the untreated negative control group (Table 1). The bacteri- 
Table 1. Influence of prepartum antibiotic treatment of heifer mammary glands with penicillin/novobiocin or pirlimycin hydrochloride on intramammary infections during early lactation.

\begin{tabular}{llllll}
\hline & & $\begin{array}{l}\text { No. heifers } \\
\text { (quarters) } \\
\text { enrolled by } \\
\text { treatment }\end{array}$ & $\begin{array}{l}\text { No. quarters } \\
\text { infected } \\
\text { before calving }\end{array}$ & $\begin{array}{l}\text { No. quarters } \\
\text { infected in } \\
\text { early } \\
\text { lactation }\end{array}$ & $\begin{array}{l}\text { Cure } \\
\text { rate }(\%)\end{array}$ \\
\hline \multirow{2}{*}{ DES $^{2}$} & Treatment $^{1}$ & $24(95)$ & 72 & 18 & 75 \\
& Penicillin/novobiocin $^{\mathrm{a}}$ & $23(92)$ & 70 & 9 & 87 \\
& Pirlimycin $^{\mathrm{a}}$ & $23(92)$ & 57 & 25 & 56 \\
MTES $^{3}$ & Untreated control $^{\mathrm{b}}$ & $19(74)$ & 25 & 6 & 76 \\
& Penicillin/novobiocin $^{\mathrm{a}}$ & Pirlimycin & & 12 & 59 \\
& Untreated control $^{\mathrm{b}}$ & $19(73)$ & 29 & 14 & 26 \\
\hline
\end{tabular}

${ }^{1}$ Cure rates of treatments within the same herd that share the same superscript are not significantly different at the $5 \%$ significance level.

${ }^{2} \mathrm{~A}$ total of 70 Jersey heifers and 279 mammary quarters was included in the study. DES = University of Tennessee Dairy Experiment Station.

${ }^{3} \mathrm{~A}$ total of 55 Holstein heifers and 213 mammary quarters was included in the study. MTES = The University of Tennessee Middle Tennessee Experiment Station.

ological cure rate was significantly higher in mammary glands of Jersey heifers treated with penicillin-novobiocin or pirlimycin during the prepartum period than in untreated controls. Five antibiotic-treated and 3 control mammary quarters developed new IMI during early lactation. The majority of IMI in Jersey heifers were due to CNS (61\%), Streptococcus species, primarily Strep. uberis (19\%) and Staph. aureus (8\%) (Table 2).

Almost 73\% of Holstein heifers (40 of 55) and 34.3\% of mammary quarters (73 of 213) were infected $14 \mathrm{~d}$ before expected calving. Of the quarters infected at 14 $\mathrm{d}$ before expected parturition, 76\% (19 of 25) were uninfected following treatment with penicillin-novobiocin; $59 \%$ (17 of 29) were uninfected following treatment with pirlimycin, and $26 \%$ (5 of 19) were uninfected in the untreated negative control group (Table 1). The bacteriological cure rate was significantly higher in Holstein heifer mammary glands treated with penicillin-novobiocin or pirlimycin during the prepartum period than in untreated controls. Ten antibiotic-treated and 12 control mammary quarters developed new IMI during early lactation. The majority of IMI in Holstein heifers was due to CNS (44\%) and Staph. aureus (30\%) (Table 3).

To our knowledge, this is the first report describing use of pirlimycin and penicillin-novobiocin for controlling heifer mastitis during the periparturient period. Pirlimycin is a lincosaminide antibiotic that functions

Table 2. Pathogens causing intramammary infections in Jersey heifers before calving and during early lactation in the Dairy Experiment Station herd.

\begin{tabular}{|c|c|c|c|c|}
\hline Mastitis pathogen & Treatment group & Before calving & Early lactation ${ }^{1}$ & Chronic $^{2}$ \\
\hline \multirow[t]{3}{*}{ CNS Species } & Penicillin/novobiocin & 49 & 12 & 3 \\
\hline & Pirlimycin & 35 & 5 & 2 \\
\hline & Control & 37 & 8 & 10 \\
\hline \multirow[t]{3}{*}{ Staphylococcus aureus } & Penicillin/novobiocin & 6 & 0 & 2 \\
\hline & Pirlimycin & 5 & 0 & 0 \\
\hline & Control & 5 & 1 & 0 \\
\hline \multirow[t]{3}{*}{ Streptococcus species ${ }^{3}$} & Penicillin/novobiocin & 4 & 0 & 0 \\
\hline & Pirlimycin & 12 & 1 & 0 \\
\hline & Control & 5 & 2 & 0 \\
\hline \multirow[t]{3}{*}{ Gram-negative $^{4}$} & Penicillin/novobiocin & 1 & 0 & 0 \\
\hline & Pirlimycin & 3 & 0 & 0 \\
\hline & Control & 2 & 0 & 0 \\
\hline \multirow[t]{3}{*}{ Mixed $^{5}$} & Penicillin/novobiocin & 12 & 1 & 0 \\
\hline & Pirlimycin & 15 & 1 & 0 \\
\hline & Control & 8 & 2 & 2 \\
\hline Total & & 199 & 33 & 19 \\
\hline
\end{tabular}

${ }^{1}$ Same pathogen isolated 7,14 , or $30 \mathrm{~d}$ after calving.

${ }^{2}$ Same pathogen isolated 7, 14 and $30 \mathrm{~d}$ after calving.

${ }^{3}$ Primarily Strep. uberis (12 of 21) and Strep. dysgalactiae subsp. dysgalactiae (6 of 21).

${ }^{4}$ Primarily Escherichia coli (5 of 6).

${ }^{5}$ Primarily Strep. uberis and CNS (26 of 35). 
Table 3. Pathogens causing intramammary infections in Holstein heifers before calving and during early lactation in the Middle Tennessee Experiment Station herd.

\begin{tabular}{llccc}
\hline Mastitis pathogen & Treatment group & Before calving & Early lactation $^{1}$ & Chronic $^{2}$ \\
\hline CNS Species & Penicillin/novobiocin & 7 & 3 & 0 \\
& Pirlimycin & 16 & 6 & 3 \\
Staphylococcus aureus & Control & 9 & 3 & 2 \\
& Penicillin/novobiocin & 5 & 1 & 1 \\
Streptococcus & Contrimycin & 9 & 3 & 0 \\
dysgalactiae subsp. & Penicillin/novobiocin & 5 & 4 & 5 \\
dysgalactiae & Pirlimycin & 1 & 0 & 0 \\
Bacillus species & Control & 0 & 0 & 0 \\
& Penicillin/novobiocin & 6 & 0 & 0 \\
Mixed & Pirlimycin & 0 & 1 & 0 \\
& Control & 0 & 0 & 0 \\
Total & Penicillin/novobiocin & 2 & 0 & 0 \\
\hline
\end{tabular}

${ }^{1}$ Same pathogen isolated 7,14 , or $30 \mathrm{~d}$ after calving.

${ }^{2}$ Same pathogen isolated 7, 14 and $30 \mathrm{~d}$ after calving.

by binding to the 50S ribosomal subunit of mRNA, inhibiting protein synthesis. Pirlimycin has been reported to be active against many gram-positive mastitis pathogens including Staph. aureus, Strep. uberis, Streptococcus dysgalactiae subsp. dysgalactiae, and Streptococcus agalactiae (Henke et al., 1988; Yancey et al., 1989). In the present study, pirlimycin was very effective in eliminating IMI due to CNS, Staph. aureus, and Strep. uberis in Jersey heifers from the DES herd and was significantly more effective than the untreated control group in the MTES herd. Results of the present study are consistent with recent studies by Gillespie et al. (2002) and Deluyker et al. (2001), who demonstrated that pirlimycin was effective in eliminating naturally occurring environmental Strep. uberis subclinical IMI, and more recently with Oliver et al. (2003a), who reported that pirlimycin was very effective in eliminating experimentally induced Strep. uberis IMI during early lactation.

The rate of prepartum infection and types of pathogens causing IMI in heifers from the 2 herds evaluated varied considerably. Almost 96\% of Jersey heifers and $71 \%$ of quarters were infected $14 \mathrm{~d}$ before expected calving. Of the IMI observed in Jersey heifers during the prepartum period, 60.8\% (121 of 199) were due to CNS, $10.6 \%$ (21 of 199) were due to environmental Streptococcus species, 8\% (16 of 199) were due to Staph. aureus, and $3 \%$ (6 of 199) were due to gram-negative pathogens primarily Escherichia coli (Table 2). In addition, 26 of 35 mixed pathogen IMI were also due to CNS and Streptococcus uberis. Far fewer Holstein heifers and quarters were infected during the prepartum period. Almost $73 \%$ of Holstein heifers and $34.3 \%$ of mammary quarters were infected $14 \mathrm{~d}$ before expected calving. Of the IMI observed in Holstein heifers during the prepartum period, $43.8 \%$ (32 of 73) were due to CNS (Table 3 ), and a much higher prevalence of Staphylococcus aureus was observed (30\% of IMI) in Holstein heifers than in Jersey heifers. Since the 2 breeds of dairy heifers used in this study were from 2 different herds, it is impossible to distinguish between a breed and a herd effect.

An equivalent percentage of prepartum IMI in heifers from both herds resulted in chronic IMI. The majority of chronic IMI in heifer mammary glands from both herds were caused by CNS (67\%) and Staph. aureus (27\%), and most chronic IMI (19 of 30) were observed in untreated control heifer mammary glands. These data suggest that in the absence of antibiotic treatment many IMI in heifers can persist for long periods of time. This is consistent with a recent report by Oliver et al. (2003b) that indicated that prepartum antibiotictreated heifers had a lower prevalence of mastitis pathogen isolation throughout lactation, and that prepartum antibiotic-treated heifers produced significantly more milk and had a significantly lower lactation average SCC score than untreated control heifers.

One common denominator observed in both herds evaluated in the present study was that CNS caused the majority of IMI in pregnant heifers during the prepartum period. This is consistent with other published reports on the prevalence of mastitis in heifers (Oliver, 1987; Oliver and Sordillo, 1988; Trinidad et al., 1990a; Pankey et al., 1991; Matthews et al., 1992; Smith et al., 1994; Fox et al., 1995; Nickerson et al., 1995). Collectively, these studies suggest that marked herd variation in the rate and types of pathogens causing IMI is common, that IMI in heifers during the prepartum period 
occur frequently, that CNS will likely cause the majority of IMI in pregnant heifers, and that variation in the prevalence of IMI in heifers should be expected among herds.

In conclusion, prepartum therapy of heifer mammary glands with penicillin-novobiocin or pirlimycin hydrochloride was effective in eliminating many infections observed during the prepartum period and for reducing the percentage of heifers and mammary quarters infected with mastitis pathogens during early lactation. However, an equivalent number of new IMI during early lactation was observed in antibiotic-treated and control mammary quarters, suggesting that prepartum antibiotic therapy as done in the present study had little effect on prevention of new IMI during early lactation. The majority of prepartum IMI in heifers were due to CNS, Streptococcus species primarily Strep. $u b$ eris, and Staph. aureus. In both herds, the bacteriological cure rate was significantly higher in heifer mammary glands treated with penicillin-novobiocin or pirlimycin hydrochloride than in untreated controls.

\section{ACKNOWLEDGMENTS}

Pfizer Animal Health, the Tennessee Agricultural Experiment Station, The University of Tennessee Food Safety Center of Excellence, and The University of Tennessee College of Veterinary Medicine Center of Excellence Research Program in Livestock Diseases and Human Health supported this work. Authors express their appreciation to personnel in the Lactation/Mastitis/ Food Safety Research Program at The University of Tennessee and to personnel at DES and MTES dairies for their excellent technical assistance.

\section{REFERENCES}

Deluyker, H. A., P. Michanek, N. Wuyts, S. N. VanOye, and S. T. Chester. 2001. We treat sick cows don't we? The case of subclinical mastitis. Proc. Natl. Mastitis Council 170-174.

Fox, L. K., S. T. Chester, J. W. Hallberg, S. C. Nickerson, J. W. Pankey, and L. D. Weaver. 1995. Survey of intramammary infections in dairy heifers at breeding age and first parturition. J. Dairy Sci. 78:1619-1628.

Gillespie, B. E., H. Moorehead, H. H. Dowlen, D. L. Johnson, K. C. Lamar, M. J. Lewis, S. J. Ivey, and S. P. Oliver. 2002. Efficacy of extended pirlimycin therapy for treatment of chronic environmental Streptococcus species intramammary infections in lactating dairy cows. Vet. Therapeutics 3:373-380.
Hallberg, J. W., K. J. Dame, S. T. Chester, C. C. Miller, L. K. Fox, J. W. Pankey, S. C. Nickerson, and L. J. Weaver. 1995. The visual appearance and somatic cell count of mammary secretions collected from primigravid heifers during gestation and early postpartum. J. Dairy Sci. 78:1629-1636.

Henke, C. L., S. T. Chester, and K. J. Dame. 1988. Pirlimycin hydrochloride intramammary infusion dose response-efficacy study in lactating dairy cows with clinical mastitis. Upjohn Technical Rep. 782-9690-88-001.

Hogan, J. S., R. Gonzalez, R. J. Harmon, S. C. Nickerson, S. P. Oliver, J. W. Pankey, and K. L. Smith. 1999. Laboratory Handbook on Bovine Mastitis. 1st ed. The National Mastitis Council, Inc., Madison, WI.

Matthews, K. R., R. J. Harmon, and B. E. Langlois. 1992. Prevalence of Staphylococcus species during the periparturient period in primiparous and multiparous cows. J. Dairy Sci. 75:1835-1839.

Nickerson, S. C., W. E. Owen, and R. L. Boddie. 1995. Mastitis in dairy heifers: initial studies on prevalence and control. J. Dairy Sci. 78:1607-1618.

Oliver, S. P., and B. A. Mitchell. 1983. Intramammary infections in primigravid heifers near parturition. J. Dairy Sci. 66:1180-1183.

Oliver, S. P. 1987. Intramammary infections in heifers at parturition and during early lactation in a herd with a high prevalence of environmental mastitis. Tennessee Farm Home Science 143:18-22.

Oliver, S. P., and L. M. Sordillo. 1988. Udder health in periparturient period. J. Dairy Sci. 71:2584-2606.

Oliver, S. P., M. J. Lewis, B. E. Gillespie, and H. H. Dowlen. 1992. Influence of prepartum antibiotic therapy on intramammary infections in primigravid heifers during early lactation. J. Dairy Sci. 75:406-414.

Oliver, S. P., M. J. Lewis, B. E. Gillespie, and H. H. Dowlen. 1997. Antibiotic residues and prevalence of mastitis pathogen isolation in heifers during early lactation following prepartum antibiotic therapy. J. Vet. Med. B 44:213-220.

Oliver, S. P., R. A. Almeida, B. E. Gillespie, S. J. Ivey, H. Moorehead, P. Lunn, H. H. Dowlen, D. L. Johnson, and K. C. Lamar. 2003a. Efficacy of extended pirlimycin therapy for treatment of experimentally-induced Streptococcus uberis intramammary infections in lactating dairy cattle. Vet. Therapeutics 4:299-308.

Oliver, S. P., M. J. Lewis, B. E. Gillespie, H. H. Dowlen, E. C. Jaenicke, and R. K. Roberts. 2003b. Milk production, milk quality and economic benefit associated with prepartum antibiotic treatment of heifers. J. Dairy Sci. 86:1187-1193.

Pankey, J. W., P. A. Dreschsler, and E. E. Wildman. 1991. Mastitis prevalence in primigravid heifers at parturition. J. Dairy Sci. 74:1550-1552.

Smith, K. L., J. S. Hogan, D. A. Todhunter, W. P. Weiss, and P. S. Schoenberger. 1994. Intramammary infection and clinical mastitis in heifers at calving and dynamics over a 14 year period in a dairy herd. J. Dairy Sci. 77(Suppl. 1):197. (Abstr.)

Trinidad, P., S. C. Nickerson, and T. K. Alley. 1990a. Prevalence of intramammary infection and teat canal colonization in unbred and primigravid dairy heifers. J. Dairy Sci. 73:107-114.

Trinidad, P., S. C. Nickerson, and R. W. Adkinson. 1990b. Histopathology of staphylococcal mastitis in unbred heifers. J. Dairy Sci. 73:639-647.

Yancey, R. J., R. A. Rzepkowski, S. T. Chester, V. N. Taylor, G. M. Baird, G. R. Bos, M. J. Frecker, J. K. Gibson, and C. W. Ford. 1989. Experimental staphylococcal mastitis in lactating dairy cows: Treated with pirlimycin hydrochloride at 100, 50, $24 \mathrm{mg} /$ quarter, Upjohn Technical Report 705-7922-89-005. 